\title{
Investigation of postural balance control in judo and handball players
}

\author{
Cengiz TASKIN ${ }^{1}$, Onder KARAKOC ${ }^{2}$, Ahmet SANIOGLU ${ }^{3}$, Mine TASKIN ${ }^{4}$
}

${ }^{1}$ School of Physical Education and Sport, University of Batman, Batman, Turkey.

${ }^{2}$ School of Physical Education and Sport, University of Gaziantep, Gaziantep, Turkey.

${ }^{3}$ Faculty of Sport Sciences, University of Selcuk, Konya, Turkey.

${ }^{4}$ Health Science Institute, University of Dumlupinar, Kütahya, Turkey.

Address Correspondence to C. Taskin, cengiz.taskin@batman.edu.tr

\begin{abstract}
The aim of this study was to examine postural balance control in hudo and handball players. A total of 50 healthy athletes that are judo and handball players participated as volunteer. The mean (SD) age was $20.96 \pm 1.18$ years, height was $1.66 \pm 0.07 \mathrm{~mm}$, and weight was $60.26 \pm 0.07 \mathrm{~kg}$ for the 23 female athletes; the mean (SD) age was $21.82 \pm 1.77$ years, height was $1.77 \pm 0.07 \mathrm{~m}$, and weight was $83.66 \pm 19.65 \mathrm{~kg}$ for the 27 male athletes. Postural balance control was evaluated using the single-legged Flamingo balance test. No significant differences were observed for female and male ( $P>0.05)$. On the other hand, we found significant differences for judo and handball players as generally $(\mathrm{P}<0.05)$. Also, we found significant differences between judo and handball for male athletes $(\mathrm{P}<0.05)$ and judo and handball for female athletes $(\mathrm{P}<0.05)$. However, we found significant differences between male judoka and female judoka $(\mathrm{P}<0.05)$. On the other hand, there are no significant differences between male handball players and female handball players $(\mathrm{P}>0.05)$. In conclusion, it was found that postural balance control of judoka is better than handball players' postural balance control. Also, it was less postural balance control of female judoka than postural balance control of female handball players. In male athletes, this was the exact opposite.

Key words: Balance, handball, judo.
\end{abstract}

\section{INTRODUCTION}

Spor has a great importance in keeping body composition, that is, keeping balance required for achievable performance. All sport technics involve balance in a certain way (17). Balance is known that it plays roles in showing many sportive skills successfully, changing directions, stopping, starting, holding, moving any object, adjusting body into a certain position (3). Balance is an important factor in keeping body composition necessary for successful performance in sport. That's why; it creates a base for dynamic sports including sudden changes in movements. All sports are made up of balance at a certain level (7). Balance is a stable and dynamic capability for having required position of body during movements. Balance consisting of motor components is provided with the links between eyesight, proprioception, vestibular organs and motor systems $(9,20)$. When each player's training level goes forward, a certain increase is observed in balance level. Long-term sportive activities and trainings, dynamic, statical postural control and sportive balance in daily life activities require perceiving internal and external stimulators and using them together. Normal balance is a combination of capability and coordination for keeping body step against the gravity powers in sportmen (8). Achieving in sport requires providing both statical and dynamic balance conditions completely (1). Postural control or balance is described as a capacity for making adjusts or maintaining adjusts in order to keep gravity center of body on support ground (13). Balance is the adjustment of muscular function and joint function and the protection of body gravity center in order to maintain the required function (16). Factors such as height, weight, gender and sport activity may affect balance performance (5). During any rest and activity, a postural adaptation to any change in gravity center affecting body is called balance (2).

Therefore, the aim of this study was to examine postural balance control in judo and handball players.

\section{MATERIAL \& METHOD}

A total of 50 healthy athletes that are judo and handball volunteered to participate in this study after having all risks explained to them before the investigation. The mean (SD) age was $20.96 \pm 1.18$ 
years, height was $1.66 \pm 0.07 \mathrm{~m}$, and weight was $60.26 \pm 0.07 \mathrm{~kg}$ for the 23 female athletes; the mean (SD) age was $21.82 \pm 1.77$ years, height was $1.77 \pm$ $0.07 \mathrm{~m}$, and weight was $83.66 \pm 19.65 \mathrm{~kg}$ for the 27 male athletes. Prior to data collection, all participants signed a university-approved consent form. After receiving a detailed explanation of the study's benefits and risks, all subject signed an informed consent document that was approved by the declaaration of Helsinki ethical principles. None of the subjects reported any medical or orthopedic problems that would compromise his participation and performance in the study. The participants' height was measured with an instrument sensitive to $1 \mathrm{~mm}$. Their body weight was measured with participants dressed in only shorts (and no shoes) with a weight-bridge sensitive up to $20 \mathrm{~g}$.

\section{Flamingo Balance Test}

Postural balance control was evaluated using the single-legged Flamingo balance test (6). Subjects were instructed to stand with their eyes open on one leg on a 1-inch-wide, 11/2-inch-high and 20-inch-long bar while the free leg was flexed at the knee joint and held at the ankle joint close to the buttocks. One minute of stance was performed and the number of falls were counted and used as a measure of postural balance $(19,14,10)$. One trial was performed for each leg interspersed by $30 \mathrm{~s}$ of rest. A 1-minute period of familiarization was performed prior to all tests. The mean value for both legs was used for further statistical analysis.

\section{Statistical Analysis}

The SPSS statistical program (version 16.0) was used for data analysis. Standard statistical methods were used for the calculation of means and SD. The Kolmogorov-Smirnov test was used to determine if dependent variables were normally distributed. The Levene test was used to determine if there was homogeneity of variance. Independent t-tests were used to determine significant differences over time for each dependent variable. For all analyses, the criterion for significance was set at an alpha level of $\mathrm{p}<0.01$.

\section{RESULTS}

As shown Table 1. The mean (SD) age was 21.82 \pm 1.77 years, height was $1.77 \pm 0.07 \mathrm{~m}$, weight was $83.66 \pm 19.65 \mathrm{~kg}$, and sport age was $7.74 \pm 2.69$ years for the male athletes; the mean (SD) age was $20.96 \pm$ 1.18 years, height was $1.66 \pm 0.07 \mathrm{~m}$, weight was $60.26 \pm 0.07 \mathrm{~kg}$, and sport age was $6.78 \pm 2.89$ years for the female athletes.
Table 1. Means and standard deviation (SD) for female and male athletes.

\begin{tabular}{clccc}
\hline \multicolumn{1}{c}{ Variables } & $\mathrm{N}$ & Mean & SD \\
\hline \multirow{4}{*}{ Male } & & & \\
& Age (years) & 27 & 21.82 & 1.77 \\
& Height $(\mathrm{cm})$ & 27 & 1.77 & 0.07 \\
& Weight $(\mathrm{kg})$ & 27 & 83.63 & 19.65 \\
& Sport age & 27 & 7.74 & 2.69 \\
& (years) & & & \\
& Age (years) & 23 & 20.96 & 1.18 \\
& Height (cm) & 23 & 1.66 & 0.07 \\
Female & Weight (kg) & 23 & 60.26 & 9.36 \\
& Sport age & 23 & 6.78 & 2.89 \\
& (years) & & & \\
\hline
\end{tabular}

Table 2. Comparison of balance score in gender and sport branches.

\begin{tabular}{lcccc}
\hline Variables & $\mathrm{N}$ & Mean \pm S.D & $\mathrm{t}$ & $\mathrm{P}$ \\
\hline Male & 27 & $10.89 \pm 3.83$ & & \\
Female & 23 & $11.35 \pm 4.60$ & 0.384 & 0.702 \\
Judo & 27 & $8.59 \pm 3.20$ & & \\
Handball & 23 & $14.04 \pm 3.14$ & 6.053 & $0.000^{*}$ \\
& & & & \\
\hline${ }^{*} \mathrm{P}<0.05$ & & & &
\end{tabular}

In comparison of balance score according to gender, no significant differences were observed for female and male ( $P>0.05)$. On the other hand, in comparison of balance score according to sport branches. We found significant differences for judo and handball $(\mathrm{P}<0.05)$.

Table 3. Comparison of balance score in sport branches according to gender.

\begin{tabular}{llccc}
\hline & Variables & Mean $\pm \mathrm{SD}$ & $\mathrm{t}$ & $\mathrm{P}$ \\
\hline \multirow{3}{*}{ Male } & Judo $(\mathrm{N}=17)$ & $9.59 \pm 3.69$ & & \\
& Handball $(\mathrm{N}=10)$ & $13.10 \pm 3.10$ & 2.523 & $0.018^{*}$ \\
\multirow{2}{*}{ Female } & Judo $(\mathrm{N}=10)$ & $6.90 \pm 0.56$ & & \\
& Handball $(\mathrm{N}=13)$ & $14.77 \pm 3.08$ & 7.919 & $0.000^{*}$ \\
& & & & \\
\hline
\end{tabular}

${ }^{*} \mathrm{P}<0.05$

Table 4. Comparison of balance score in gender according to sport branches.

\begin{tabular}{|c|c|c|c|c|}
\hline \multicolumn{2}{|c|}{ Variables } & Mean \pm SD & $\mathrm{t}$ & $\mathrm{P}$ \\
\hline \multirow{2}{*}{ Judo } & \multirow{2}{*}{$\begin{array}{l}\text { Male } \\
(\mathrm{N}=17) \\
\text { Female } \\
(\mathrm{N}=10)\end{array}$} & $9.59 \pm 3.69$ & & \\
\hline & & $6.90 \pm 0.56$ & 2.269 & $0.032^{*}$ \\
\hline \multirow{2}{*}{ Handball } & $\begin{array}{l}\text { Male } \\
(\mathrm{N}=10)\end{array}$ & $13.10 \pm 3.10$ & \multirow{2}{*}{1.282} & \multirow{2}{*}{0.214} \\
\hline & $\begin{array}{c}\text { Female } \\
(\mathrm{N}=13)\end{array}$ & $14.77 \pm 3.08$ & & \\
\hline
\end{tabular}

We found significant differences between judo and handball for male athletes $(\mathrm{P}<0.05)$. Also, there are significant differences between judo and handball for female athletes $(\mathrm{P}<0.05)$. 
We found significant differences between male judoka and female judoka $(\mathrm{P}<0.05)$. On the other hand, there are no significant differences between male handball players and female handball players $(\mathrm{P}>0.05)$.

\section{DISCUSSION}

Judo is a sport which in balance and coordination must be at the highest level and which always develops them. The most fundamental thing for judo is that body movements and any component's balance ways must be known. When a handball player is precluded with personal contact by a defense player while he is shooting a ball to the goal post, this situation affects the players' balance negatively and so the players' normal balance is under danger. The player coordinates his body by correctly positioning his gravity center within stability limitations in order to prevent himself from falling down and does not fall down (8). There is a positive correlation between coordination and motoric characteristics obtained at the early ages. Certain results shown by tests: ones who regularly do sport during all their lives present better results than ones never doing sport. Sportive process also improves postural system affecting balance (4). It is observed that balance capacity has a great role in players' performance and measures for their injuries. It is not certain whether doing regular trainings and participating in sportive activities without special balance trainings change balance capacity (12). Sterkowicz et al. (18)'s study dealt judo as a strength and endurance sport in general. In this sport, adapting to some movements depend on coordination and balance (18). Perrin et al. (15) stated that judo education was a significant component of balance control had a positive effect on sensory adaptation and was a way for the best performance in order to have a steady position in every condition. Also, the technics learned about balance strategies by high-level judo players must have been given in treatment programs in case players with non-problematic balance may be injured (15). This literature study supports judo trainings have positive effects on balance and complies with our research findings. Hrysomallis (11) studied the effects of balance education on sportive performance and motor skills said that balance trainings were efficient in motor skills and strength increase. Even though there was limited information showing the effects of balance trainings on elite players' motor skills. Balance trainings increased performance more (11).
In conclusion; any statistically significant differences were not found between the male sportmen's balance scores and the female players' balance scores when compared to the balance scores of the players involved in the research in accordance with the gender. On the contrary, a statistically significant difference was found to be fairly high in the balance scores of handball players rather than the balance scores of judo players when comparing the balance scores of judo players and handball players. High scores indicate that faults are more in the balance test. So judo players can be said to be more balanced than handball players.

\section{REFERENCE}

1. Altay F. Ritmik cimnastikte iki farklı hıda yapılan "Chaine Rotasyon" sonrasinda yan denge hareketinin biomekanik analizi. Doktora Tezi. Hacettepe Üniversitesi Sağlık Bilimleri Enstitüsü. Ankara. 2001.

2. Baltacı G. Bayrakçı TV. Tuncer A. Spor Yaralanmalarında Egzersiz Tedavisi. Ankara: Alp Yayınları. 2006.

3. Bompa T. Antrenman Kuramı ve Yöntemi. Ankara: Bağırgan Yayınevi. 1998; 36-41.

4. Böer JR. Charakterisierung des balance verhaltens von gesunden. hüft-und kniepatienten auf dem posturomed. Eberhard Karls Universität. 2006.

5. Davlin CD. Dynamic balance in high level athletes. Percept Mot Skills, 2004; 98:1171-1176.

6. Deforche B. Lefevre J. De BI. Hills AP. Duquet W. Bouckaert J. Physical Wtness and physical activity in obese and nonobese Flemish youth. Obes Res, 2003; 11: 434-441.

7. Eler S. Bir sezonluk antrenman periyotlaması boyunca üst düzey erkek hentbolcuların bazı motorik ve fizyolojik parametrelerinin incelenmesi. Yüksek Lisans Tezi. Gazi Üniversitesi Sağlık Bilimleri Enstitüsü. Ankara. 1996.

8. Erkmen N. Sporcuların denge performanslarının karşılaştırılması. Doktora Tezi. Gazi Üniversitesi Sağlık Bilimleri Enstitüsü. Ankara. 2006.

9. Guyton AC. Hall JE. Textbook of Medical Physiology. Eleventh Edition. Elsevier. 2006.

10. Helge EW. Aagaard P. Jakobsen MD. Sundstrup E. Randers MB. Karlsson MK. Krustrup P. Recreational football training decreases risk factors for bone fractures in untrained premenopausal women. Scand J Med Sci Sports. 20(Suppl 1). 2010; 31-39.

11. Hrysomallis C. Balance ability and athletic performance. Sports Medicine. 2011; 41(3):221-232.

12. Hrysomallis C. Preseason and midseason balance ability of professional Australian Footballers. Journal of Strength and Conditioning Research. 2008; 22 (1). 210.

13. Kean CO. Behm DG. Young WB. Fixed foot balance training increases rectus femoris activation during landing and jump height in recreationally active women. Journal of Sports Science and Medicine, 2006; 5:138-148.

14. Krustrup P. Christensen JF. Randers MB. Pedersen H. Sundstrup E. Jakobsen MD. Krustrup BR. Nielsen JJ. Suetta C. Nybo L. Bangsbo J (2010) Muscle adaptations and 
performance enhancements of soccer training for untrained men. Eur J Appl Physiol, 108(6):1247-1258.

15. Perrin P. Judo better than dance develops sensory motor adapt abilities involved in balance control. Gait and Posture, 2002; 15: 187-194.

16. Ragnasrdottir M. The Concept of Balance Physiotherapy. 1996.

17. Sandrey MA. The comparative effects of a six-week balance training program. Gluteus medius strength training program and combined balance training/gluteus medius strength training program on dynamic postural control. Master of
Science in athletic training. School of Physical Education. Morgantown. West Virginia. 2006.

18. Sterkowicz S. Coordination motor abilities of judo contestants at different age. 2012.

19. Sundstrup E. Jakobsen MD. Andersen JL. Randers MB. Petersen J. Suetta C. Aagaard P. Krustrup P. Muscle function and postural balance in life long trained male footballers compared with sedentary elderly men and youngsters. Scand J Med Sci Sports. 2010; 20(Suppl 1): 90-97.

20. Wilmore JH. Costil DL. Physiology of Sport and Exercise. Third Edition. Human Kinetics. 2004: 35-36. 